\title{
相撲力士の死亡率とその要因について
}

\author{
星秋夫, 稲 葉裕 \\ 順天堂大学医学部衛生学教室
}

\section{Risk Factors for Mortality and Mortality Rate of Sumo Wrestlers}

\author{
Akio HOSHI and Yutaka INABA \\ Department of Epidemiology and Environmental Health, Juntendo University School of Medicine, Tokyo
}

\begin{abstract}
We compared the mortality rate of sumo wrestlers with that of the contemporaneous Japanease male population, and inferred the usefulness of an index for predicting longevity in sumo wrestlers. The standardized mortality ratios (SMR) for sumo wrestlers were very high in each period, and also high for ages from 35 to 74 . Cox's proportional hazards model analysis revealed that the variables in "nyuumaku" entry year and BMI were statistically significant $(p<0.05)$ factors in mortality. In the survival curves, the lower BMI group had good life expectancy compared with the higher BMI group. In conclusion, the higher rate of mortality in sumo wrestlers seems to be due to the markedly higher rate of mortality from 35 to 74 years old. In sumo wrestlers, also, this study provides evidence that the higher overweight groups have substantially higher risks for mortality.
\end{abstract}

Key words: Sumo wrestler (相撲力士), Mortality rate (死亡率), SMR (年齢標準化死亡比), Cox's proportional hazards model（此例ハザードモデル）

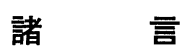

ヒトの寿命には, そのライフスタイルが大きく影響し， 適度な強度のスポーツや運動習慣は健康や寿命に対して よい影響を，過体重は悪影響を及ぼすことがハーバード 大学の卒業生を対象とした Paffenbargerらの追跡研 究1 4) において指摘されている。しかし, 青少年期に激し い運動を実施するスポーツ選手の寿命については諸外国 において古くから多くの研究がなされているが長 命5),6), 変わらない( ${ }^{7)}$, 短命 ${ }^{8), 9)}$ と研究者によりその報告は 異なり, 延命効果については知見が一致しておらず, 我 が国においてはわずかな報告10),11) があるのみである。

ところで, 我が国伝統のスポーツである相撲は勝つた め, あるいは昇進するためには体重を増加させることが
重要である特殊なスポーツである。このことから, 相撲 力士は特徵的な生活習慣を有し, 形態的な特徵として“超 肥満体”があげられ, 機能面においても有酸素性能力の 低いことが指摘 ${ }^{12)}$ されている。また, 糖尿病等の疾患の 発生率が高いことが報告13),14) されており, 力士の寿命に 対して影響を及ぼしているとも考えられる。しかし，前 述したように我が国においてはスポーツ選手の寿命に関 する報告は少なく, 力士の寿命についての検討も不十分 である。

そこで本研究では相撲力士の死亡率について検討する とともに，力士における種々の要因の死亡率に及ぼす影 響の大きさについて検討した。

Reprint requests to: Akio Hoshi, Department of Epidemiology and Environmental Health, Juntendo University, 2-1-1 Hongo, Bunkyo-ku, Tokyo 113, Japan 


\section{方法}

\section{1. 調査対象}

調查した集団は日本相撲協会に所属し，1898 年から 1991 年までに幕内に入幕した全力士 664 名である。この うち外国人力士は 5 名であったが, 全員が生存し, 少人 数であることを考え，除外しなくとも結果へ及ぼす影響 はそれほど大きくないと判断し, 調査対象に加えた。な お，引退した者も「力士」と総称し，観察した。

\section{2. 資料収集方法}

資料の収集は大相撲力士名鑑15)より行った。この本は 幕内に昇進した全力士の出生日, 死亡日（死亡している 場合)，出身地，初土俵，十両昇進，入幕，最終場所(引 退した場合)，最高位，幕内成績，勝率，年寄り株の有無， 現役時における身長，体重を著したものである。なお， 死亡の確認に対して, 名鑑には死亡年月日不詳があり, 印刷ミスの可能性もあるので相撲博物館保存の死亡者記 録より，1992 年 12 月 31 日までの死亡を確認し，双方を 照合して正確を期し，最終的には死亡者記録の方をその 資料とした。

\section{3. 分析方法}

1）年齢標準化死亡比 (SMR)

各対象は入幕年から 1992 年 12 月 31 日以前の死亡日 までの年数を加え，人年を計算した。期待死亡数は 1900 年以降 1990 年までの 5 年ごとの人口動態統計により 5 歳年齢階級別死亡率を基準として算出した。すなわち， $1988 \sim 1992$ 年の 5 年間の年齢階級別観察人年に 1990 年 の年齢階級別死亡率をかけ合わせて加えたものが, 1988〜1992 年の期待死亡数となる。そして, 観察死亡数 と期待死亡数の比から SMR を求めた。SMR の統計学 的検定は $\chi^{2}$ 検定を用いた。

2) $\operatorname{Cox}$ の比例ハザードモデル

死亡率に対する各要因の寄与の推定の解析において, 1897 年以前の出生者は観察期間中にすべて死亡し, 死亡 の期待值が求められないことから 1898 年以後の出生者 512 名を解析対象とした。解析に際して最高位，年寄り 株, $\mathrm{BMI}\left(\right.$ 体重 $/$ 身長 $\left.^{2} \times 100\right)$ ，入幕時暦年，入幕年齢，お よび現役期間を説明変数として Cox の比例ハザードモ デルを用いて解析した。説明変数の最高位は大関以上と 関脇以下, 年寄り株の有無, 入幕時暦年は 1954 年以前と 1955 年以後の 2 段階に区分し, BMI は 32.9 以下, $33.0 \sim 41.9,42.0$ 以上, 入幕年齢は 21 歳以下, $22 \sim 25$, 26 歳以上, 現役期間は 65 力月以下, 66 99 カ月, 100 力 月以上の 3 段階に区分した。各要因の影響を比較しやす
くするため， 3 段階に区分した説明変数は，それぞれ中 值群は除いて, 高值群と低値群とを比較した。その後, 八ザードモデルで有意であった因子について，生存率の 計算を Kaplan-Meier 法, 検定を一般化 Wilcoxon 法を 用いて因子の有無別の生存率を検討した。

なお，統計処理は統計パッケージ HALBAU を用い， 危険率 $5 \%$ 以下をもって有意とした。

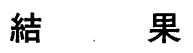

\section{1. カ土のプロフィール}

対象者 664 名のうち, 1992 年末における生存者は 328 名, 死亡者は 328 名, 死亡年月日不明の者 8 名であった。 このうち大関以上に昇進した者 86 名，それ以下の者 578 名であり，1 年以上年寄り株を所有した者 347 名，それ 以外の者 317 名である。対象群のプロフィールは Table 1 に示したが, その特徴として BMI が著しい高值を示し た。

\section{SMR}

table 2 に年齢階級別，年次別の観察人年を示す。 1958 1962 年の 35〜39 歳がもっとも多く，これが 5 年 ずつ，ずれていく様子が明らかである。また， 95 年間の 総観察人年は $18,127.00$ であった。

table 3 には対象群の特性をみるために, 総死亡につい て年次別, 年齢階級別に観察死亡数, 期待死亡数, SMR を示した。年次区分は戦前と戦後に区分し，戦後におい てはさらに 3 つに区分した。な押，5歳年齢階級別の観 察死亡数が少ないことから 10 歳年齢階級で示した。総計 でみると, 期待死亡数 197.8, 観察死亡数 328, SMR 1.66 で $1 \%$ の危険率で有意差を認めた。年次別にみると 1898～1947 年に抢ける SMR は 1.64，1948～1962 年は $1.39 ， 1963 \sim 1977$ 年は $1.97 ， 1978 \sim 1992$ 年は 1.60 と戦 前戦後を通じ，いずれの年次においても $1 \%$ の危険率て 有意差を認めた。年齢別にみると，34 歳以下の SMR は $0.87,35 \sim 44$ 歳は $1.75(\mathrm{p}<0.01), 45 \sim 54$ 歳は 2.24 $(\mathrm{p}<0.01), 55 \sim 64$ 歳は $1.98(\mathrm{p}<0.01), 65 \sim 74$ 歳は

Table 1 Profile of Sumo Wrestlers.

\begin{tabular}{lcc}
\hline & mean \pm SE & range \\
\hline Height $(\mathrm{cm})$ & $177.5 \pm 7.2$ & $159.0-214.0$ \\
Weight $(\mathrm{kg})$ & $115.8 \pm 24.9$ & $71.0-262.0$ \\
BMI $\left(\mathrm{kg} / \mathrm{m}^{2}\right)$ & $36.6 \pm 6.6$ & $25.0-74.9$ \\
Nyuumaku age $(\mathrm{yr})$ & $24.4 \pm 3.1$ & $17-38$ \\
Nyuumaku year $(\mathrm{yr})$ & $1947.5 \pm 5.3$ & $1898-1991$ \\
Length of wrestling (mo) & $81.0 \pm 5.9$ & $1-212$ \\
\hline
\end{tabular}


日衛誌(Jpn. J. Hyg.) 第 50 巻 第 3 号 1995 年 8 月

Table 2 Observed Person Years of Five-Year Age Groups.

\begin{tabular}{|c|c|c|c|c|c|c|c|c|c|c|c|c|c|}
\hline \multicolumn{14}{|c|}{ Age Group } \\
\hline Year & $\sim 19$ & $\sim 24$ & $\sim 29$ & $\sim 34$ & $\sim 39$ & $\sim 44$ & $\sim 49$ & $\sim 54$ & $\sim 59$ & $\sim 64$ & $\sim 69$ & $\sim 74$ & $75 \sim$ \\
\hline $1898 \sim 1902$ & 1.00 & 6.50 & 7.00 & 4.50 & 0 & 0 & 0 & 0 & 0 & 0 & 0 & 0 & 0 \\
\hline $1903 \sim 1907$ & 0.50 & 13.00 & 40.00 & 21.00 & 10.00 & 0 & 0 & 0 & 0 & 0 & 0 & 0 & 0 \\
\hline $1908 \sim 1912$ & 1.50 & 36.00 & 78.50 & 83.50 & 36.00 & 10.50 & 0 & 0 & 0 & 0 & 0 & 0 & 0 \\
\hline $1913 \sim 1917$ & 0 & 29.25 & 126.00 & 147.00 & 82.50 & 37.00 & 6.50 & 0 & 0 & 0 & 0 & 0 & 0 \\
\hline $1918 \sim 1922$ & 0 & 21.00 & 127.00 & 164.50 & 141.50 & 78.50 & 35.50 & 6.00 & 0 & 0 & 0 & 0 & 0 \\
\hline $1923 \sim 1927$ & 0 & 22.00 & 113.50 & 154.50 & 160.00 & 128.50 & 68.50 & 26.50 & 3.00 & 0 & 0 & 0 & 0 \\
\hline $1928 \sim 1932$ & 1.50 & 20.00 & 104.50 & 156.50 & 152.50 & 139.50 & 108.00 & 53.50 & 19.50 & 3.00 & 0 & 0 & 0 \\
\hline $1933 \sim 1937$ & 0 & 36.00 & 123.50 & 153.50 & 160.50 & 138.00 & 124.00 & 79.50 & 42.50 & 18.50 & 3.00 & 0 & 0 \\
\hline $1938 \sim 1942$ & 0.50 & 48.00 & 120.00 & 162.50 & 137.50 & 140.00 & 123.50 & 109.00 & 62.50 & 32.00 & 18.00 & 3.00 & 0 \\
\hline $1943 \sim 1947$ & 0.50 & 67.00 & 138.00 & 140.50 & 154.50 & 129.00 & 123.50 & 105.00 & 74.50 & 44.50 & 19.00 & 13.00 & 0.50 \\
\hline $1948 \sim 1952$ & 0 & 42.00 & 194.00 & 173.00 & 129.50 & 141.00 & 118.50 & 113.00 & 84.00 & 57.00 & 30.50 & 13.50 & 0 \\
\hline $1953 \sim 1957$ & 0 & 36.00 & 139.50 & 256.50 & 171.00 & 128.00 & 136.00 & 109.00 & 101.50 & 71.50 & 47.00 & 18.50 & 3.00 \\
\hline $1958 \sim 1962$ & 2.00 & 82.50 & 122.50 & 167.50 & 263.50 & 169.00 & 117.50 & 130.50 & 96.00 & 78.50 & 57.00 & 32.00 & 15.50 \\
\hline $1963 \sim 1967$ & 0.50 & 92.50 & 201.50 & 130.00 & 164.00 & 248.00 & 155.50 & 112.00 & 115.00 & 80.50 & 54.50 & 32.50 & 25.50 \\
\hline $1968 \sim 1972$ & 2.50 & 75.50 & 178.50 & 211.00 & 127.00 & 154.00 & 226.00 & 152.50 & 100.50 & 97.00 & 61.50 & 34.50 & 26.50 \\
\hline $1973 \sim 1977$ & 1.50 & 62.00 & 176.00 & 193.00 & 208.50 & 121.50 & 152.50 & 209.00 & 126.00 & 68.50 & 73.50 & 47.00 & 22.50 \\
\hline $1978 \sim 1982$ & 0 & 46.00 & 163.00 & 192.00 & 190.50 & 203.00 & 109.50 & 140.50 & 183.50 & 88.50 & 57.50 & 51.00 & 38.50 \\
\hline $1983 \sim 1987$ & 0 & 55.00 & 128.50 & 185.00 & 187.00 & 187.50 & 189.00 & 100.50 & 130.50 & 171.50 & 60.00 & 37.00 & 58.00 \\
\hline $1988 \sim 1992$ & 2.50 & 51.75 & 143.50 & 156.50 & 187.00 & 191.00 & 182.00 & 186.00 & 93.50 & 122.00 & 145.00 & 53.50 & 60.00 \\
\hline
\end{tabular}

Total Person Years $=18,127.00$.

Table 3 Standardized Mortality Ratio by Calendar Year and Age Group.

\begin{tabular}{|c|c|c|c|c|c|c|c|c|}
\hline \multicolumn{9}{|c|}{ Age Group } \\
\hline Year & & $\sim 34$ & $\sim 44$ & $\sim 54$ & $\sim 64$ & $\sim 74$ & $75 \sim$ & Total \\
\hline \multirow[t]{3}{*}{$1898 \sim 1947$} & $\mathrm{O}$ & 20 & 32 & 37 & 18 & 5 & 0 & 112 \\
\hline & $\mathrm{E}$ & 21.61 & 17.55 & 15.40 & 9.59 & 3.95 & 0 & 68.10 \\
\hline & SMR & 0.93 & 1.82 & 2.40 & 1.88 & 1.27 & 0 & $1.64^{* *}$ \\
\hline \multirow[t]{3}{*}{$1948 \sim 1962$} & $\mathrm{O}$ & 2 & 6 & 15 & 17 & 17 & 1 & 58 \\
\hline & $\mathrm{E}$ & 4.31 & 4.44 & 6.89 & 10.91 & 12.98 & 2.16 & 41.69 \\
\hline & SMR & 0.46 & 1.35 & 2.18 & 1.56 & 1.31 & 0.46 & $1.39^{* *}$ \\
\hline \multirow[t]{3}{*}{$1963 \sim 1977$} & $\mathrm{O}$ & 2 & 10 & 15 & 25 & 29 & 11 & 92 \\
\hline & $\mathrm{E}$ & 1.95 & 4.43 & 8.36 & 9.64 & 13.29 & 8.99 & 46.66 \\
\hline & SMR & 1.03 & 2.26 & 1.79 & 2.59 & 2.18 & 1.22 & $1.97^{* *}$ \\
\hline \multirow[t]{3}{*}{$1978 \sim 1992$} & $\mathrm{O}$ & 1 & 2 & 11 & 17 & 20 & 15 & 66 \\
\hline & E & 0.97 & 2.08 & 4.22 & 8.77 & 10.96 & 14.35 & 41.35 \\
\hline & SMR & 1.03 & 0.96 & 2.61 & 1.94 & 1.82 & 1.05 & $1.60^{* *}$ \\
\hline \multirow[t]{3}{*}{ Total } & $\mathrm{O}$ & 25 & 50 & 78 & 77 & 71 & 27 & 328 \\
\hline & $\mathrm{E}$ & 28.84 & 28.50 & 34.87 & 38.91 & 41.18 & 25.5 & 197.8 \\
\hline & SMR & 0.87 & $1.75^{* *}$ & $2.24^{* *}$ & $1.98^{* *}$ & $1.72^{* *}$ & 1.06 & $1.66^{* *}$ \\
\hline
\end{tabular}

O: Observed Number of Deaths.

E: Expected Number of Deaths.

**; Significant at $1 \%$ level.

SMR: O/E.

$1.72(\mathrm{p}<0.01), 75$ 歳以上は 1.06 であり 35〜 74 歳まで

の SMR が有意に高值を示した。

\section{3. 力士の平均死亡年齢}

力士の死亡年齢 (平均士標準偏差 (最小〜最大) ) は 
$56.0 \pm 14.2(22 \sim 87)$ 歳であるが, 年次別にみると $1898 \sim 1947$ 年における死亡年齢の平均は $46.0 \pm$ 11.1 (23〜 75) 歳, 1948～1962 年は 57.5士 $11.2(33 \sim 82)$ 歳, 1963～1977 年は $60.6 \pm 12.0(27 〜 85)$ 歳, 1978〜1992 年は $65.2 \pm 12.9(22 \sim 87)$ 歳と, 近年に近ずくにしたが い, その平均死亡年齢は有意 $(\mathrm{p}<0.01)$ に増加している。

\section{Coxの比例ハザードモデル}

死亡に対する各要因の寄与の推定をするために，説明 変数として, 最高位, 年寄り株, BMI, 入幕時暦年, 入 幕時年齢, 現役期間を用いて Cox の比例ハザードモデル による解析を行った結果を table 4 に示す。入幕時暦年 において，1954 年以前の入幕群に対する 1955 年以後の 入幕群の死亡率の相対危険度は 0.17 (逆数で 6.08 ) であ り, 1954 年以前の入幕群は 1955 年以後の入幕群よりも 死亡率の高い $(\mathrm{p}=0.024)$ ことが認められた。また, BMI において, 32.9 以下の低值群を基準にすると 42.0 以上 の高值群における死亡率の相対危険度は 3.66 となり, 高 值群は低值群よりも死亡率の高い（ $\mathrm{p}=0.012 ）$ ことが認
められた。しかし, 最高位, 年寄り株, 入幕時年齢, お よび現役期間の要因の差による影響は認められなかっ た。

有意であった 2 因子について一般化 Wilcoxon の検 定により累積生存率を検討した。Fig. 1 に示すように入 幕暦年については $1 \%$ 危険率で有意差が認められた。 BMI については Fig. 2 に示すように $5 \%$ の危険率で有 意差が認められた。また, 1954 年以前の入幕者のみで同 じ検討を行った際の結果も同じように低值群での生存率 が有意 $(\mathrm{p}<0.01)$ に高かった。

\section{考察}

本研究の資料に関しては, 戸籍や死亡診断書のような 正確な記載はない。しかしながら, 社会的に注目されて いる集団でもあり, 全体で 664 名という力士の生死はあ る程度確実に把握されていると考える。もし, 脱落して いる者があるとしても，第 2 次大戦前の少数例のみであ ろうと推察している。生存に関しては, 少し信頼性は落

Table 4 Relative Risk for Mortality in Analysis using Cox's Proportional Harzards Model.

\begin{tabular}{lccccccc}
\hline Variable & $\beta$ & STD-error & $\mathrm{t}$ & $\mathrm{F}$ & $\mathrm{P}$ & $\mathrm{R} . \mathrm{R}$ & $95 \% \mathrm{CI}$ \\
\hline Ranking & -0.058 & 0.554 & -0.10 & 0.011 & 0.918 & 0.94 & $0.34-2.95$ \\
Toshiyori & -0.258 & 0.391 & -0.66 & 0.435 & 0.511 & 0.77 & $0.36-1.66$ \\
BMI & 1.298 & 0.509 & -2.55 & 6.501 & 0.012 & 3.66 & $1.35-9.95$ \\
N. Y & -1.805 & 0.792 & -2.28 & 5.198 & 0.024 & 0.17 & $0.04-0.78$ \\
& & & & & & $(6.08)$ & $(1.29-28.70)$ \\
N. A & 0.051 & 0.410 & 0.13 & 0.016 & 0.901 & 1.05 & $0.47-2.35$ \\
L. W & -0.039 & 0.503 & -0.08 & 0.006 & 0.938 & 0.96 & $0.36-2.58$ \\
\hline
\end{tabular}

R. R: Relative risk. 95\%CI: $95 \%$ confidence interval. N. Y: Nyuumaku Year. N. A: Nyuumaku Age. L. W: Length of Wrestling. $95 \% \mathrm{CI}=\exp (\beta \pm 1.96 \times \mathrm{STD}$-error $)$.

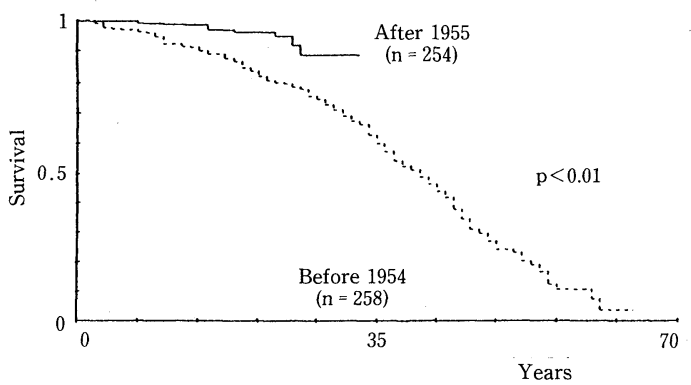

Fig. 1 Survival curves by "nyuumaku" year of sumo wrestlers; before 1954 and after 1955 .

Toshiyore: $+1-$.
Ranking: above Ozeki/below Sekiwake.

BMI: over $42.0 /$ under 32.9 .

N. Y: after 1955/before 1954 (reciprocal).

N. A: $\geqq 26$ years old/ $\leqq 21$ years old.

L. W: over 100 months/under 65 months.

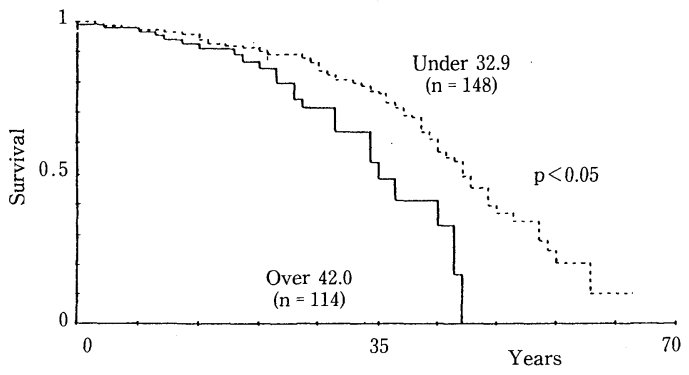

Fig. 2 Survival curves of sumo wrestlers by BMI; under 32.9 and over 42.0. 
ちるが，100 歳以上という力士は認められず，特に 1955 年以後の入幕の力士に関しては確実であると考えてい る。

本研究における対象群のSMR は戦前戦後を通じいず れの年次に扔いても有意に高值を示した(表 3 )。年齢階 級別にみると $35 \sim 75$ 歳の SMR が有意に高いことから, 力士の高い SMR は 35 75 歳の年齢層の SMR が反映 しているものと示唆される。しかし, 34 歳以下の年齢の SMR 0.87 と有意ではないが低い傾向にある。その要 因として, 対象群においては若年時に病弱者が力士とし て入門するとは考えられず，入門時にスポーツの実施で きる体格や体力の優れた者のみの集団であること, 入幕 に至らず途中淘汰された力士が除外されていることが影 響していると考えられる。そして, 競技生活の影響は 35 歳以上の年齢に表れた可能性が推察される。

過体重が種々の疾患を招来する13),16),17) ことはすでに 知られており，寿命に悪影響を及活す ${ }^{16,18)}$ ことも認めら れている。スポーツ選手において, Rook ${ }^{8)}$ は陸上競技選 手を短距離, 長距離, ハンマー投げに分類し, これらグ ループの 70 歳以上生存した割合を比較した結果, 短距離 $57 \%$, 長距離 $56 \%$, ハンマー投げ $34 \%$ と, より体重のあ る選手群が短命であると報告している。本研究における 力士の BMI は平均 36.6 (25.0 74.9) と著しい高值を示 す。したがって,力士の高いSMR の要因の一つとして過 体重が考えられる。

Karvonen ${ }^{5)}$ は距離スキー選手の寿命は一般人よりも 長く, 引退後にも身体活動を継続し，低い喫煙率が寿命 の延長に寄与したことを報告している。Paffenberger $ら^{1 \sim 4)}$ はハーバード大学の卒業生の追跡調査において, 適度な強度のスポーツや運動習慣は寿命によい影響を, 喫煙や高血圧, 過体重は寿命に悪影響を及ほすを報告し ている。これらのことから，寿命に及ほす寸要因としては 比較的短期間の競技生活よりもその後の長期間にわたる ライフスタイルの影響の方が大きい可能性もある。本研 究の力士の引退後におけるライフスタイル等の資料がな く,引退後における生活の影響については不明であるが, 力土の引退年齢は平均 31.6 歳と若い年齢で引退してお り, 本研究においても引退後のライフスタイル等が寿命 に影響している可能性が考えられる。

力士の平均死亡年齢は 1898〜1947 年においては 46.0 歳であったが,近年に近ずくにつれて延長し, 1978〜1992 年では 65.2 歳に達している。人口動態統計を基に 1925 年と 1985 年の年齢階級別死亡者数から 20 歳以上男子の 平均死亡年齢を推計すると,それぞれ 56.1 歳, 69.1 歳と
なる。SMR 同様, 力士の平均死亡年齢は両年代ともに日 本人男子の平均よりも低值を示す。しかし，その差異は 近年の方が小さい。このことは現在は力士に対して健康 診断が年 2 回実施されているなど，力士に対する健康管 理の充実や保健医療の進歩等に起因しているのかもしれ ない。

死因については約半数が死因不明のため結果に示して いないが 1978〜1992 年の過去 15 年間についてみると死 亡者 66 名中 13 名 $(19.7 \%)$ が死因不明であり，死亡者 数も少ないことから断定的な結論を下すわけにはいかな いが，不明者を除く死因の割合は心疾患 15 名(28.3\%), 悪性新生物 10 名 (18.9\%), 脳血管系疾患 8 名 (15.1\%) の順になっている。同期間における日本人男子の三大死 因の死亡総数に対する割合を人口動態統計より算出する と, 悪性新生物 $(27.5 \%)$, 心疾患 $(17.9 \%)$, 脳血管系 疾患 $(16.9 \%)$ となり, 力士の心疾患による死亡の割合 が大きいことが推察される。肥満者の心疾患による死亡 率は標準体重者よりも高いことが報告 ${ }^{19), 20) さ れ て い る 。 ~}$ それゆえ，力士の高い心疾患による死亡は力士の過体重 に起因しているものと推察される。

力士の死亡率に寄与する要因としては競技生活の影響 のみならず，長い引退後の生活の影響も考えられ，引退 後のライフスタイルや体組成等の要因についても検討す べきである。なぜなら，力士の死亡率に及ぼす影響が競 技生活に起因するものか, 引退後の生活に起因するもの か，あるいはどちらの影響が大きいのか明らかにできる と考えられるからである。しかし，引退後における資料 がないことから，本研究では競技生活の影響についての み検討することとし，現役時代における各力士の資料を 基に Cox の比例ハザードモデルによる解析から力士の 死亡率に寄与する要因を推定した。死亡率に寄与する要 因として最高位，年寄り株の有無，入幕年齢，現役期間 については抽出されず，力士時代の強さ，若い年齢で入 幕した影響, 力士として，あるいは年寄りとして相撲界 にとどまった期間は死亡率に影響を及ぼさないことが認 められた。しかし死亡率に寄与する要因として, 入幕暦 年, BMI が抽出された。

入幕暦年に関しては，1954 年以前の入幕者は 1955 年 以後の入幕者よりも死亡率が高いという結果であった。 また，生存曲線において，1955 年以後の入幕者はそれ以 前の入幕者に比べ観察期間 35 年時点での生存率が高い。 この要因として，まず考えられることは，小川ら ${ }^{21}$ が年 寄りの死因を戦前と戦後で比較した結果，肺炎による死 亡の占める割合は戦前の $12.1 \%$ から戦後の $2.1 \%$, 腸 
チフスは $6.1 \%$ から $0 \%$ へ減少したと報告している点が ある。それゆ光, 1955 年以後の入幕者の死亡率の低下は 各種感染症による死亡の低下や健康管理の充実など, 保 健医療の進歩等が影響している可能性がある。また, 1955 年以後の入幕者はそれ以前の入幕者に比べ観察期間が短 期間であることも考えられる。

BMI において, 高值群 (42 以上) は低值群 (33 以下) よりも死亡率が有意に高く, 現役時の過体重が力士の死 亡率に影響を及ぼしていることが示唆された。前述した ように過体重は寿命に対して悪影響を及ぼす16 18),20),22) ことはすでに知られている。力士においては血圧, 尿酸 值, 血糖值は入門後, 体重増加に従い増加すること帛, 力 士の糖尿病等の罹患率が高いこと ${ }^{13,14)}$, が報告されてお り,すでに力士時代において過体重に起因する疾患や不 可逆的変化が起こり始めていることが認められている。 引退後における健康管理等が影響することから, これら の要因が高い死亡率に対してすべて反映しているとは考 えられないが, 引退後の死亡率に対して影響を及ほして いることは十分に考えられる。また, Lee ら ${ }^{23)}$ は八ー バード大学卒業生の体重変化と寿命について検討した結 果, BMI の高值群は低值群よりも死亡率が高值を示すば かりでなく, $5 \mathrm{~kg}$ 以上の体重変動のあった者はそれ以下 の者よりも死亡率が高いと報告している。すでに過体重 である力士が引退後に現役時の体重を維持したのか隇量 をしたのかは不明であるが, 過体重を改善するために減 量をしたとすれば, BMI の高値群では低值群よりも体重 の変動が大きくなると考えられ, 体重を維持しても, 減 量をしても, どちらにせよ BMI の高值群は低值群より も死亡率が高くなると思われる。

1955 年以降の入幕者において, 入幕暦年と BMI との 間に正の相関関係 $(\mathrm{r}=0.368, \mathrm{P}<0.001)$ が認められた。 現役時の BMI の高值群は低值群に比べ, 死亡率が高い という本結果から推察すると力士の死亡率に対して今後 さらに悪影響を及ぼす可能性が考えられる。このように， 力士の体型 (BMI) が大型化してきているにもかかわら ず，力士の死亡平均年齢は近年に近ずくにつれて延長し てきている。このような結果をもたらした要因として, 対象となる力士は 1955 年以降の入幕者であり, 年齢も若 く死亡者も入幕者 254 名中 20 名にすぎず, 1978 1992 年に打ける死亡者の入幕年の内訳は 1916 1932 年の入 幕者が 15 名, 1933 1947 年が 29 名, 1948〜1962 年が 19 名, 1963〜1977 年が 2 名, そして 1978〜1992 年が 1 名と 近年に近い入幕者の死亡者はきわめて少ない。それゆえ， 近年においても力士の平均死亡年齢は 1955 年以降の入
幕者よりもそれ以前の入幕者をより反映していると考え られる。したがって，1955 年以降の入幕者の死亡率を検 討するには現時点では観察期間が短く, 大型化の影響は 今後現れてくるのかもしれない。今後の死亡率の変化を 注目していきたい。

以上のことから, 力士は一般人よりも過体重であり, 過体重に起因する疾患の罹患率も高い。これが力士の高 い死亡率の要因の一つとなっていることが考えられた。 これを改善するには現役時においては, 過体重になりす ぎないことが重要である。それゆえ, 力士は勝つため, あるいは強くなるために過体重になることから, 健康と 勝負の選択は難しい問題ではあるが, 現役時の力士に対 する健康管理や保健指導等を充実させる必要性があると 考えられる。過体重者は低い者に比べ死亡率の高いこと， 体重の大きな変化は死亡率を高める可能性があることを 考えると, 引退後においては極端な体重変化は避け, 健 康管理に留意することが大切であると考えられる。

\section{要約}

1898 年から 1991 年までに幕内に入幕した力士 664 名 を対象に, 力士の年齢標準化死亡比 (SMR) について同 時代の日本人男性と比較した。さらに, 1898 年以降の出 生者を対象として死亡率に対する種々の要因の寄与の推 定を行った。

その結果は以下の通りである。

1. 力士の SMR はいずれの年次においても有意に高 く, 年齢階級別にみると, 35〜 74 歳の SMR が有意に 高かった。

2. Cox の比例ハザードモデルによる解析から力士の 死亡率に寄与する要因として, 入幕暦年, BMI が抽出 された。

3. 生存率曲線に扔いて, 入幕暦年の高値群, BMI の低 值群はそれぞれ低值群, 高值群よりも生存率が高かっ た。

以上の結果から相撲力士の高い死亡率は 35〜 74 歳の 高い死亡率によるものと示唆され, 力士において, BMI の高值群は死亡のリスクが高いことが明らかとなった。

\section{文献}

1) Paffenbarger, R.S.Jr., Wing, A.L., Hyde, R.T. and Jung, D.L.: Physical activity and incidence of hypertension in college alumni, Am. J. Epidemiol., 117, 245-257 (1983).

2 ) Paffenbarger, R.S.Jr., Hyde, R.T., Wing, A.L. and 
Hsieh, C-c.: Physical activity, all-cause mortality, and longevity of college alumni, N. Engl. J. Med., 314, 605-613 (1986).

3 ) Paffenbarger, R.S.Jr., Hyde, R.T., Wing, A.L. and Hsieh, C-c.: Physical activity and longevity of college alumni, N. Engl. J. Med., 315, 399-401 (1986).

4 ) Paffenbarger, R.S.Jr., Hyde, R.T., Wing, A.L., Lee, I-M., Jung, D.L. and Kampert, J.B.: The association of changes in physical-activity level and other lifestyle charactersitics with mortality among men, N. Engl. J. Med., 328, 538-545 (1993).

5 ) Karvonen, M.J., Klemola, H., Virkakajarvi, J. and Kekkonen, A.: Longevity and endurance skiers, Med. Sci. Sports, 6, 49-51 (1974).

6 ) Prout, C.: Life expectancy of college oarsman, J. A.M.A., 220, 1709-1711 (1972).

7 ) Beaglehole, R. and Stewart, A.: The longevity of international rugby players, NZ. Med. J., 96, 513 -515 (1983).

8 ) Rook, A.: An investigation into the longevity of Cambridge sportsmen, Br. Med. J., (i), 773-777 (1954).

9 ) Dublin, L.L.: Longevity of college athletes, Harpen's Mag., 157, 569-579 (1928).

10）小磯 透, 大澤清二：わが国におけるスポーツマン の寿命に関する研究, 厚生の指標, 38, 22-27(1991).

11）中嶋英昭, 佐々龍雄, 橋羽裕規男, 小川新吉: 柔道 高段者の健康と生命調査, 体力科学, 32, 225-226 (1983).

12）小川新吉, 永井信雄, 山本善伯, 中嶋英昭 : 相撲力 士の体力科学的研究, 体力科学, 21, 118-128(1972).

13）入江 実, 葛谷 健: 力士および肥満者の糖代謝, 糖尿病, 12, 307-310（1969）。

14）杉本良一, 阿部正和, 種瀬富男, 池田碵子, 高橋忠
雄, 川村真人, 小山勝一, 菊池陽三, 小川新吉, 勝

田 茂, 春山国広：力士の糖尿病発現頻度に関する 調査成績, 体力科学, 12, 160-165（1963）.

15）水野尚文, 京須利敏編著 : 大相撲力士名鑑, 共同通 信社, 東京 (1992)。

16) Sorlie, P., Gordon, T. and Kannel, W.B.: Body build and mortality, the Framingham Study, JAMA, 243, 1828-1831 (1980).

17) Wilson, P.W.F., McGee, D. and Kannel, W.B.: Obesity, very low density lipoproteins, and glucose intolerance over fourteen years: The Framingham Study, Am. J. Epidemiol., 114, 697 -704 (1981).

18) Vandenbroucke, J.P.: Weight, smoking, and mortality, JAMA, 252, 2859-2860 (1984).

19）野々宮広章, 若野紘一, 山田公雄, 山崎 元, 大西 祥平, 勝川史憲: 大相撲力士のメディカルチェック, 体力科学, 40, 985 (1991).

20) Hubert, H.H., Feinlieb, M., McNamara, P.M. and Castelli, W.P.: Obesity as an independent risk factor for cardiovascular disease: A 26-year follow-up of participants in the Framingham Heart Study, Circulation, 67, 968-977 (1983).

21）小川新吉, 古田善伯, 永井信雄, 山本恵三, 美濃部 浩一：元相撲力士 (年寄) の健康状態に関する研究, 東京教育大学体育学部スポーツ研究所報, 11, 1-14 (1973).

22) Kannel, W.B., Le Bauer, E.T., Dawber, T.R. and McNamara, P.M.: Relation of body weight to development of coronary heart disease, Circulation, 35, 296 (1967).

23) Lee, I-M. and Paffenberger, R.S.Jr.: Changes in body weight and longevity, JAMA, 268, 2045-2049 (1992).

（受付 1993 年 8 月 4 日 受理 1995 年 1 月 27 日） 